\title{
IDENTIFICATION OF LEPTOSPIRA SEROVARS BY RESTRICTION-ENDONUCLEASE ANALYSIS
}

\author{
R. B. Marshall, B. E. Wilton and A. J. Robinson \\ Department of Veterinary Pathology and Public Health, Faculty of Veterinary Science, Massey \\ University, Palmerston North, New Zealand
}

\section{Plates XIII-XV}

\begin{abstract}
SUMmaRY. Strains of Leptospira interrogans were examined by restrictionendonuclease analysis. Serovars hardjo and balcanica gave patterns that differed from each other, and from those of other members of the Hebdomadis serogroup and members of other serogroups. The method should be useful for the identification of leptospires and might throw light on problems of their classification.
\end{abstract}

\section{INTRODUCTION}

In the genus Leptospira there are two species, interrogans, comprising the potential pathogens, and biflexa, comprising the free-living saprophytic forms (International Committee on Systematic Bacteriology, Subcommittee on Taxonomy of Leptospira, Munich 1978, to be published). The species interrogans contains at least 130 serovars, which have been placed into 18 serogroups on the basis of antigenic relatedness. Different serogroups are routinely distinguished by microscopic agglutination tests with group-specific antisera. To ensure reproducible results in the identification of serovars, Kmety (1967) proposed the use of factor sera. These are produced by multiple absorption of antisera to reference strains, reducing the agglutinin content to a single main factor. Preparation of all the antisera necessary for factor analysis is a daunting task. Other methods examined include comparisons of DNA-base composition (Haapala et al., 1969), immunodiffusion analysis of axial-filament antigens (Change, Faine and Williams, 1974) and studies of the properties of lipases and other enzymes (Bakoss and Chorvath, 1965; Green, Goldberg and Blenden, 1967). However, for routine use no method has superceded the microscopic agglutination test.

In recent years, restriction-endonuclease analysis has been used to identify isolates of human papilloma virus (Gissman, Pfister and Zur Hausen, 1977), herpes simplex virus I and II (Buchman et al., 1978; Linnemann et al., 1978; Lonsdale, 1979), orthopoxviruses (Esposito, Obijeski and Nakano, 1978), and orf virus (A. J. Robinson and T. C. Balassu, personal communication). The method consists of extraction of DNA from a homogeneous population of organisms, digestion of the DNA with a restriction endonuclease, and electrophoresis of the digested DNA in an agarose gel. Because restriction endonucleases recognise and cleave double-stranded DNA at specific 4 or 6 base-pair sequences, a set of fragments is generated. The migration of these fragments in agarose gel is related to molecular weight; a pattern of bands is produced that can be seen in the gel by ultraviolet light if stained with ethidium bromide, or by autoradiography if labelled with ${ }^{32} \mathrm{P}$. These patterns constitute a characteristic "fingerprint" for any particular DNA.

In New Zealand we are often faced with the problem of differentiating the only two members of the Hebdomadis serogroup known to occur in the country, L. interrogans serovars hardjo and balcanica. Both commonly occur in animals and are potential human pathogens. They are closely related serologically. The problem of identifying them was chosen to test the potential usefulness of restriction-endonuclease analysis in the field of leptospirosis. 


\section{MATERIALS AND METHODS}

Bacterial strains. The hardjo strains were: nos. 08/1, 017/6, 39/1, 10797, H3/1, MD1W31 and MD1W38 (all from cattle); and 535, Gr5/7, Gr5/9 (from sheep). The balcanica strains were: nos. E32, E39, T78, W88, WR 18, and WR57 (from possums); and G16, G68, and G84 (from goats). Strains 39/1, 535, E32, E39 and T78 had been typed by the Center for Disease Control (CDC), Atlanta, Ga 30333, USA. Strains 017/6, H3/1, G16, G68, and G84 had been typed by the Wallaceville Animal Research Centre, Private Bag, Upper Hutt, New Zealand. The remainder had been identified only as far as serogroup. In addition, all the isolates were tested for haemolysis, a procedure found by Hathaway and Marshall (1980) to be helpful in distinguishing balcanica from hardjo. At the Wallaceville Animal Research Centre isolates of hardjo are distinguished from balcanica by means of a rapid but limited factor-sera method; if any isolate belonged to a serovar of the Hebdomadis serogroup other than serovars hardjo or balcanica, the method would not be able to identify it. Strains of serovars other than hardjo and balcanica were also used in this study; these serovars, all of which came originally from the CDC, were hebdomadis (Hebdomadis), szwajizak (Szwajizak), sejroe (KM), pomona (Pomona), tarassovi (Mitis Johnson), ballum (Mus 127), copenhageni (M20), australis (Ballico), and medanensis (Hond HC).

Preparation of DNA. Leptospiral DNA was extracted by the method of Fischer and Lerman (1979). Each strain to be tested was cultured in $20 \mathrm{ml}$ of EMJH Medium (Difco Laboratories, Detroit, Michigan, USA) for 5 days at $30^{\circ} \mathrm{C}$; the concentration of organisms produced was approximately $1 \times 10^{8} / \mathrm{ml}$. Each culture was centrifuged at $12100 \mathrm{~g}$ for $30 \mathrm{~min}$ and the pellet resuspended in TEB, consisting of $10 \mathrm{mM}$ Tris- $\mathrm{HCl}, \mathrm{pH} \mathrm{8.5}$, and $10 \mathrm{~mm}$ ethylenediamine tetracetic acid sodium salt (EDTA). Centrifugation followed by resuspension of the pellet in TEB was repeated twice to remove all traces of culture medium. The final pellet was resuspended in $1 \mathrm{ml}$ of TEB; $100 \mu \mathrm{L}$ of an aqueous solution of grade 1 lysozyme $(3 \mathrm{mg} / \mathrm{ml}$; Sigma Chemical Co., St Louis, Mo 63178 , USA) were added. After incubation at $37^{\circ} \mathrm{C}$ for $15 \mathrm{~min}, 100 \mu \mathrm{L}$ of a $10^{\circ} \%$ aqueous solution of specially pure sodium lauryl sulphate (BDH Chemicals, Poole, Dorset) and $100 \mu \mathrm{L}$ of an aqueous solution of Pronase (10 mg/ml; Calbiochem, San Diego, Ca 92112, USA) were added. Incubation was continued overnight at $50^{\circ} \mathrm{C}$. Solid sodium perchlorate was then added to a concentration of $1 \mathrm{M}$. The mixture was incubated for another hour at $50^{\circ} \mathrm{C}$ and made up to a volume of $5 \mathrm{ml}$ with STE ( $150 \mathrm{mM} \mathrm{NaCl}, 10 \mathrm{mM}$ Tris-HCl, $p \mathrm{H} 8 \cdot 5$, and $1 \mathrm{mM}$ EDTA); it was then extracted three times with a mixture of phenol, chloroform, and isoamyl alcohol $(25: 24: 1)$ previously saturated with STE. After extraction each sample was dialysed exhaustively against

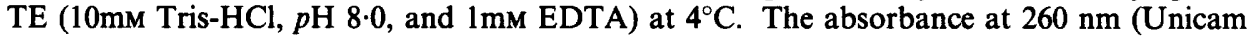
spectrophotometer, SP500) of each preparation was measured in a quartz-glass cell with a 1-cm light path; it was assumed that one optical-density unit was equivalent to double-stranded DNA $50 \mu \mathrm{g} / \mathrm{ml}$. Because RNA had not been selectively removed from the preparations, its presence would have contributed to the absorbance at $260 \mathrm{~nm}$. Initially, to calculate the contribution of RNA to the absorbance, the DNA content of each preparation was also measured by fluorimetry (Le Pecq and Paoletti, 1966). The DNA concentration measured by the latter method gave a result $10-50 \%$ lower than that measured by the absorbance; it was concluded that the difference represented the contribution of RNA. Subsequently the DNA contribution to the absorbance was assumed to be $75 \%$ and the DNA concentration of each preparation was calculated accordingly.

Restriction endonuclease digestion of DNA. Initially 1.0-2.0 $\mu \mathrm{g}$ of bacterial DNA was digested to completion at $37^{\circ} \mathrm{C}$ for $1 \mathrm{~h}$ with 4 units of $E C o R_{1}$ restriction endonuclease (a generous gift from Dr P. Berquist, University of Auckland) in $100 \mu \mathrm{L}$ of a buffer containing

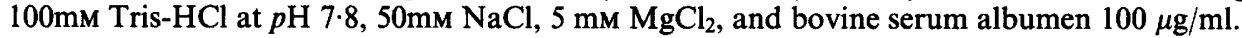
Subsequently a commercial preparation of the same enzyme was used (New England Biolabs, Beverly, Ma, 01915, USA).

Gel electrophoresis and photography. Gel electrophoresis was done by the method of McDonnell, Simon and Studier (1977). Each sample was placed in the wells of a horizontal slab of agarose (Bio-Rad, Richmond, Ca 94804, USA). Electrophoresis was maintained for 4-5 h at $4 \mathrm{~V} / \mathrm{cm}$ in $0.7 \%$ agarose gels, and overnight at $0.5 \mathrm{~V} / \mathrm{cm} \mathrm{in} 0.3 \%$ agarose gels. The electrophoresis

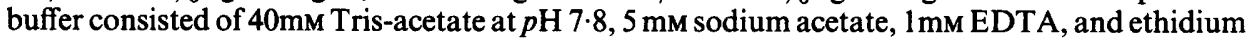


bromide $0.5 \mu \mathrm{g} / \mathrm{ml}$. The agarose was dissolved in electrophoresis buffer by boiling in a flask fitted with a reflux condenser. The agarose was cooled to $40^{\circ} \mathrm{C}$ before pouring. After electrophoresis the gel was illuminated with ultraviolet light and photographed by a method similar to that of Sharp, Sugden and Sambrook (1973). Gels were placed on a filter plate measuring $15 \times 15 \mathrm{~cm}$ (Ultraviolet Products, San Gabriel, Ca 91778, USA) in a light box illuminated from below by four 15-W germicidal ultraviolet lamps (Philips, Eindhoven, Holland).

The gels were photographed on Kodak Tri-X film by means of a 120 format plate camera through a Wratten 23A gelatin filter.

\section{RESULTS}

Figs. 1, 2, 3 and 4 show the results of agarose-gel electrophoresis of $\mathrm{ECoR}_{1}$ restrictionendonuclease digests from some leptospiral strains, serovars and serogroups. Hardjo and balcanica produced patterns that differed distinctly from each other (figs. 1 and 2), from those produced by laboratory strains of other members of the Hebdomadis serogroup (fig. 3), and from those produced by members of other serogroups (fig. 4).

\section{Discussion}

Serovars hardjo and balcanica were clearly distinguished from each other by restrictionendonuclease analysis. There was no detectable variation in the $\mathrm{ECoR}_{1}$ endonuclease "fingerprints" between isolates from different species of animal, or between isolates from the same species but from widely separated geographic areas within New Zealand. Restriction-endonuclease analysis of other members of the Hebdomadis serogroup and of representatives from other serogroups revealed that all these organisms could be distinguished from each other. Although $\mathrm{ECoR}_{1}$ endonuclease did not reveal differences between different strains belonging to the same serovar, other endonucleases might detect minor variations. It also seems possible that restriction-endonuclease analysis could be used for the direct identification of leptospires in body fluids such as urine, though limiting factors would be the number of organisms present and the degree of contamination with other organisms.

The technique may also throw light on the classification of organisms within the genus Leptospira. The present allocation of serovars of Leptospira interrogans into serogroups is essentially a consequence of the technique of serological typing and does not appear to have any other biological significance. On the other hand, the serovar of a strain is almost invariably related to biological characteristics. It is therefore encouraging that our results clearly separated serovars rather than serogroups. The technique may prove useful in identifying bacteria other than leptospires.

We thank Professor B. W. Manktelow for his advice in preparing the manuscript and Mrs Alison Lee and Mr Rex Faulding for technical assistance.

\section{REFERENCES}

BaKoss, P. AND ChORvath, B. 1965. Contribution à l'étude de propriétés immunologiques des lipases des leptospires. Rapport préliminaire. Archs Inst. Pasteur Tunis., 42, 171.

Buchman, T. G., Roizman, B., Adams, G. AND Stover, B. H. 1978. Restriction endonuclease fingerprinting of herpes simplex virus DNA: a novel epidemiological tool applied to a nosocomial outbreak. J. inf. Dis., 138, 488.

Chang, A., FAINe, S. AND Williams, W.T. 1974. Cross-reactivity of the axial filament antigen as a criterion for classification of Leptospira. Aust. J. exp. Biol. med. Sci., 52, 549.

Esposito, J. J., OBIJESKI, J. F. AND NAKANo, J. H. 1978. Orthopoxvirus DNA: strain differentiation by electrophoresis of restriction endonuclease fragmented virion DNA. Virology, 89, 53.

FISCHER, S. G. AND LERMAN, L. S. 1979. Length-independent separation of DNA restriction fragments in two-dimensional gel electrophoresis. Cell, 16, 191. 
Gissman, L., Pfister, H. and Zur Hausen, H. 1977. Human papilloma viruses (HPV): characterisation of four different isolates. Virology, 76, 569.

Green, S. S., GoldBerg, H. S. AND Blenden, D. C. 1967. Enzyme patterns in the study of Leptospira. Appl. Microbiol., 15, 1104.

HaApala, D. K., Rogul, M., Evans, L. B. and Alexander, A. D. 1969. Deoxyribonucleic acid base composition and homology studies of Leptospira. J. Bact., 98, 421.

Hathaway, S. C. and Marshall, R. B. 1980. Haemolysis as a means of distinguishing between Leptospira interrogans serovars balcanica and hardjo. J. med. Microbiol., 13, 477.

KMETY, E. 1967. Faktorenanalyse von Leptospiren de Icterohaemorrhagiae und einiger verwandter Serogruppen. Slovenska Akadéma Vied; Bratislava, (Biologicke prace 13, no. 3).

Le PecQ, J. B. AND PaOletTi, C. 1966. A new fluorometric method for RNA and DNA determination. Analyt. Biochem., 17, 100.

Linnemann, C. C., Buchman, T. G., Light, I. J., Ballard, J. L. and Roizman, B. 1978. Transmission of herpes-simplex virus type 1 in a nursery for the newborn. Identification of viral isolates by DNA "fingerprinting". Lancet, $\mathbf{i}, 1964$.

LONSDALE, D. M. 1979. A rapid technique for distinguishing herpes simplex virus type 1 from type 2 by restriction-enzyme technology. Lancet, i, 849 .

MCDonell, M. W., Simon, M. N. AND Studier, F. W. 1977. Analysis of restriction fragments of T7DNA and determination of molecular weights by electrophoresis in neutral and alkaline gels. J. molec. Biol., 110, 119.

Sharp, P. A., Sugden, B. AND SAMBrooK, J. 1973. Detection of two restriction endonuclease activities in Haemophilus parainfluenzae using analytic agarose ethidium bromide electrophoresis. Biochemistry, 12, 3055. 


\section{IDENTIFICATION OF LEPTOSPIRES BY DNA ANALYSIS}

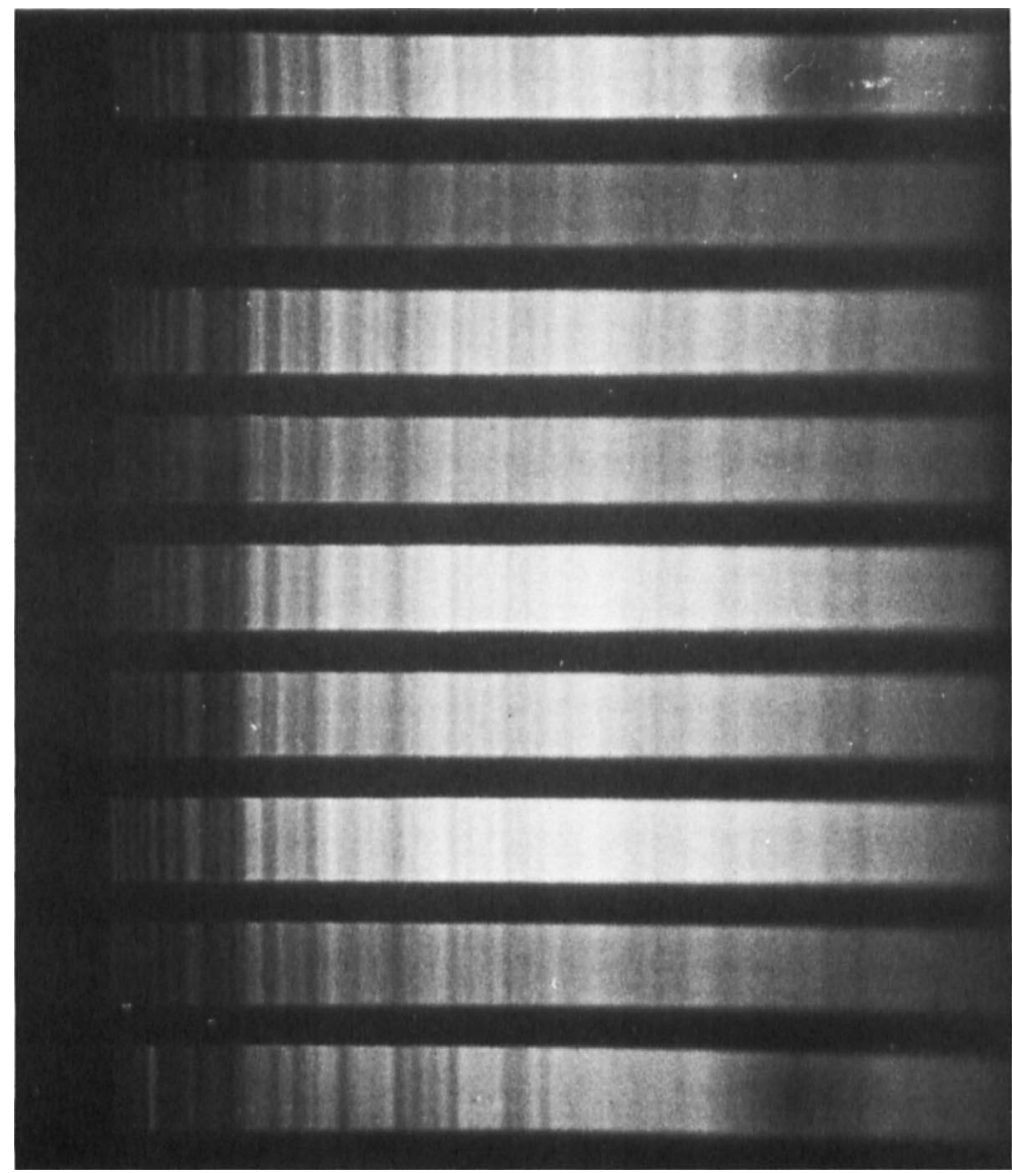

FIG. 1.-Restriction-endonuclease analysis of one strain of Leptospira interrogans serovar balcanica and eight strains of serovar hardjo. From bottom to top, balcanica strain T78, and hardjo strains $017 / 6$, 39/1, 535, Gr5/9, 10797, MD1W38, H3/1 and 08/1. 
IDENTIFICATION OF LEPTOSPIRES BY DNA ANALYSIS

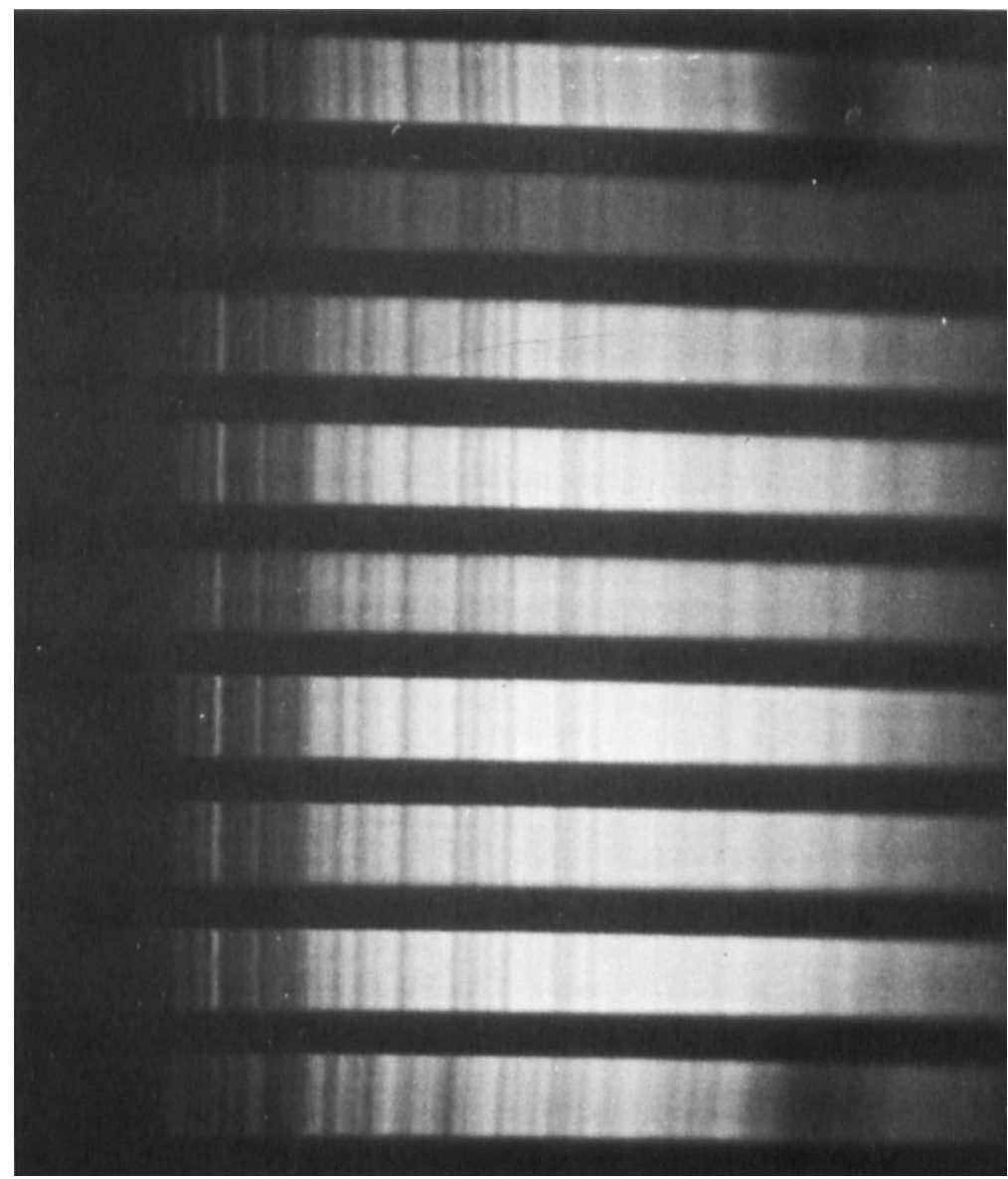

FIG. 2.--Restriction-endonuclease analysis of one strain of serovar hardjo and eight strains of serovar balcanica. From bottom to top, hardjo strain MD1W31, and balcanica strains E32, E39, T78, WR18, WR57, G84, G16 and G68. 


\section{IDENTIFICATION OF LEPTOSPIRES BY DNA ANALYSIS}
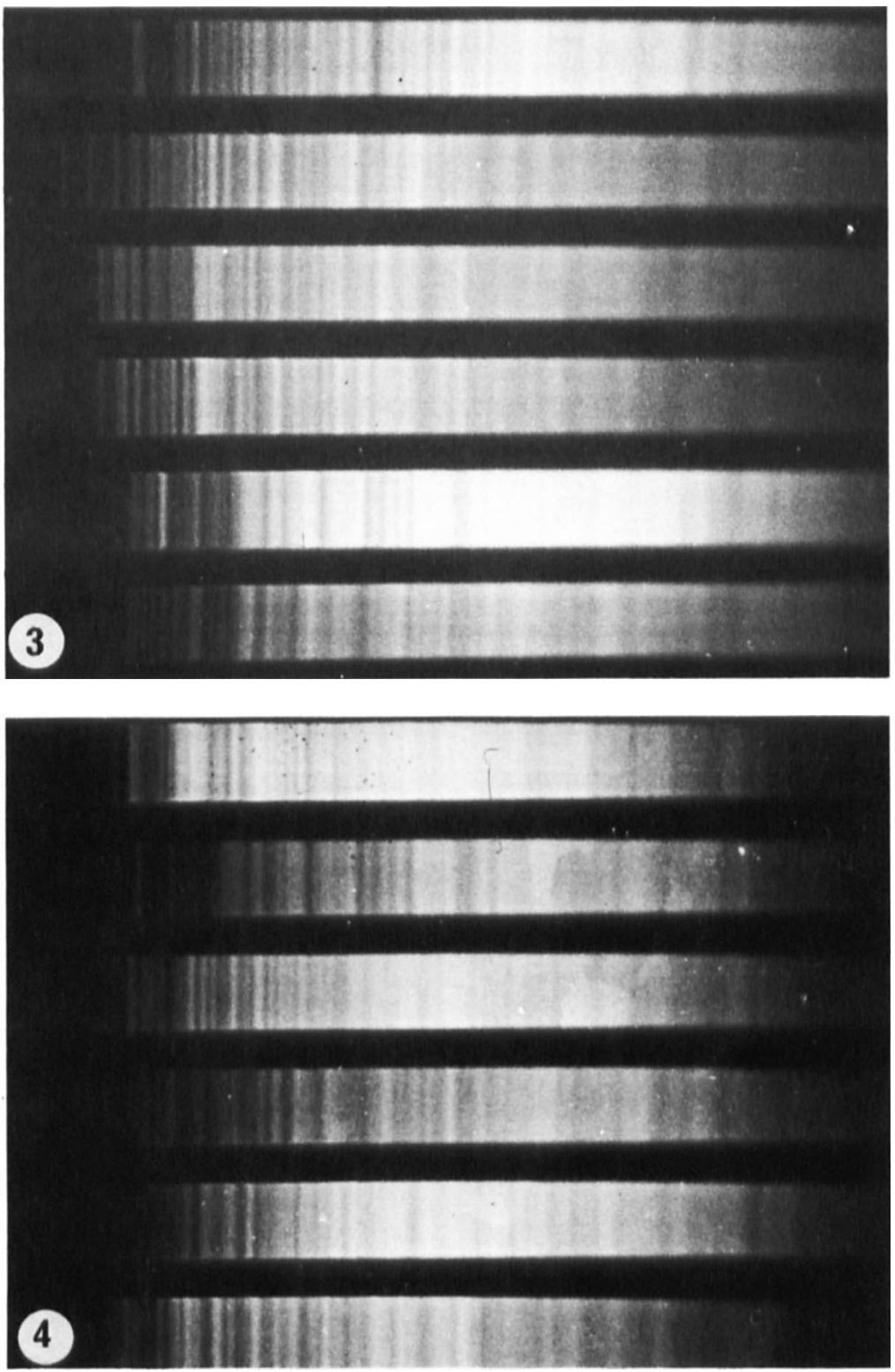

FIG. 3.-Restriction-endonuclease analysis of six leptospiral strains belonging to different serovars of the Hebdomadis serogroup. From bottom to top, serovars hardjo (Gr5/7), balcanica (T78), hebdomadis, medanensis, szwajizak and sejroe.

FIG. 4.-Restriction endonuclease analysis of six leptospiral strains belonging to serovars of six different serogroups. From bottom to top, serovars pomona, tarassovi, ballum, copenhageni, balcanica (W88), and australis. The pattern for pomona has been transposed from another photograph and is to the same scale. 